\title{
Palm Versus Soybean Oil on Intestinal Recovery from Malnutrition in Guinea Pigs
}

\author{
MARIE-AGNÈS PÉLISSIER, NATHALIE BOURDET, FLORE MARQUES-DOSSOU, \\ JEHAN-FRANÇOIS DESJEUX, AND ROBERT ALBRECHT \\ Conservatoire National des Arts et Métiers, Laboratoire de Biologie, 75003 Paris, France
}

\begin{abstract}
Recent recommendations on feeding malnourished children do not provide indication on the nature of dietary lipids. Our aim was to compare the effect of palm oil (mainly saturated and monounsaturated fatty acids) and soybean oil (mainly polyunsaturated fatty acids) on the recovery from malnutrition in guinea pigs. In a first experiment, guinea pigs received a balanced (control group) or a maize (malnourished group) diet for 7, 12, and $21 \mathrm{~d}$. In a second experiment, after $12 \mathrm{~d}$ of malnutrition, guinea pigs received a rehabilitation diet containing palm or soybean oil. Both rehabilitation diets allowed a partial recovery from the severe weight loss induced by malnutrition. Thiobarbituric acid reactive substances content, measured in intestinal homogenates, increased in malnourished guinea pigs compared with control animals $(40 \%, p<0.05)$ and returned to near control values after rehabilitation with palm (10\%) but not soybean $(43 \%)$ oil diet. Intestinal short-circuit current, assessed in jejunal segments mounted in Ussing chambers, increased
\end{abstract}

\section{ABSTRACT}

progressively during malnutrition $(p<0.001)$ and returned to near control values with both rehabilitation diets. Compared with control animals, the cell turnover (Ki-67 index assessed by immunohistochemistry detection of the Ki-67 antigen) decreased after soybean $(-60 \%, p<0.01)$ but not after palm oil. These results confirm that experimental polydeficient malnutrition induces oxidative stress and dysfunction in the intestine. They show a differential effect of palm and soybean oil on these intestinal measurements, suggesting that the composition of dietary lipids may be important in the treatment of malnutrition.

(Pediatr Res 52: 119-124, 2002)

G, ionic conductance

\section{Abbreviations}

PD, potential difference

Isc, short-circuit current

Tbars, thiobarbituric acid reactive substances
Malnutrition cannot be considered solely as a deficiency in protein and energy, as multiple mineral, vitamin, and other essential nutrient deficiencies are also involved (1), including deficiencies in antioxidant vitamins (2-4). In children, there is clinical evidence that malnutrition is associated with low levels of antioxidant endogenous defenses (5-7) and high exposure to oxidants $(8)$, including free iron $(9,10)$. This may cause the dysfunction of various tissues during malnutrition, including the intestine. In the rat, we have previously shown that oxidative stress is likely to be involved in the altered epithelial transport associated with malnutrition (11).

The present World Health Organization recommendation for the dietary management of severely malnourished children is the use of a diet based on dried skimmed milk, sugar, cereal flour, and vegetable oil in adequate proportions, supplemented with special mineral mix and vitamin mix (12). Although no indication is provided on the nature of the oil to include in these therapeutic diets, soybean and rapeseed oils are often

Received March 5, 2001; accepted December 20, 2001.

Correspondence and reprint requests: Marie-Agnès Pélissier, $\mathrm{PhD}, \mathrm{CNAM}$, Laboratoire de Biologie, 2 rue Conté, 75003 Paris, France; e-mail: pelissie@cnam.fr

DOI: 10.1023/01.PDR.0000016663.42264.7B used, because they are given in the context of international food aid programs.

Inasmuch as malnutrition is associated with an increased oxidative stress, the composition of the oil should be taken into account for its therapeutic management. Red palm oil has the potential to be a very useful nutrient in developing countries: it possesses a good oxidative stability owing to tocopherols and tocotrienols; moreover it provides carotenoids, and can be locally produced in many countries at a competitive price (13). The fatty acid composition of palm oil is quite different from that of other vegetable oils. It is mainly composed of palmitic acid (a saturated fatty acid) and oleic acid (a monounsaturated fatty acid also present in olive oil), whereas soybean oil is mainly composed of linoleic acid (a polyunsaturated fatty acid).

Because monounsaturated fatty acids are less prone to oxidation than polyunsaturated fatty acids (14), the former may confer antioxidant activity to the diet, whereas the latter may rather promote oxidative stress. For this reason, we hypothesized that palm and soybean oils may have a different effect in promoting the recovery from malnutrition. To test this hypothesis, we used a previously described model of malnutrition $(100 \%$ maize) in the guinea pig (15), in which severe intestinal 
dysfunctions could be quantitatively assessed and, in addition, the lipid content of the rehabilitation diet provided approximately $27 \%$ of the energy from fat compared with a standard guinea pig diet ( $9 \%$ of the energy from fat) because the recommended diet for treatment of malnutrition is also enriched with lipids to a higher level. Finally, the aim of the study was not to mimic the complexity of childhood malnutrition; rather it was aimed at comparing the effects of two different vegetable oils on specific intestinal measurements in an experimental model of malnutrition. The results point to the importance of taking into account the nature of dietary lipids for further research in the treatment of childhood malnutrition.

\section{METHODS}

Animals, diets, and tissue preparation. Weanling 2-wk-old male Dunkin-Hartley guinea pigs, weighing 190-210 g (Charles River, Saint Aubin les Elbeuf, France), were submitted to two different dietary protocols (Fig. 1). Animal use was reviewed and approved by the Institutional Animal Care of the Ministry of Agriculture. A first experiment (malnutrition study) was designed to test the feasibility of an experimental model of severe malnutrition and to select the time for rehabilitation. We did not use the previous model as such (15) because of a high degree of mortality (approximately 50\%) among the guinea pigs receiving a deficient diet for $28 \mathrm{~d}$. Sixty

\section{First experiment}

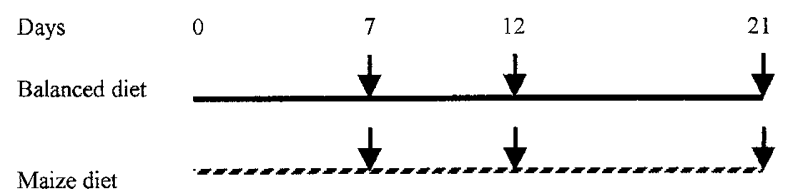

Maize diet M

\section{Second experiment}

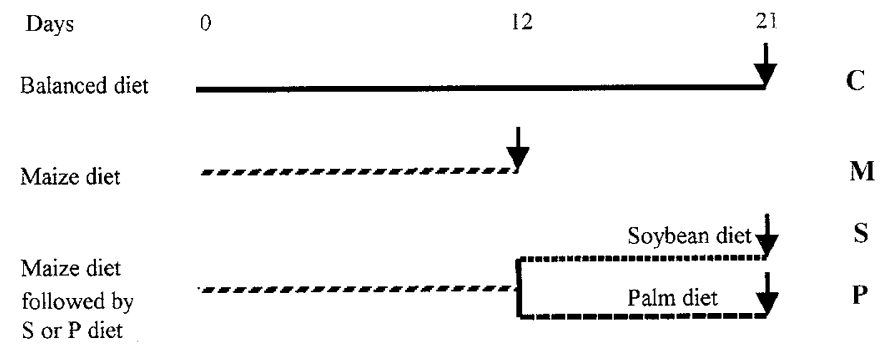

Figure 1. Dietary protocols. The control diet $(C)$ is a standard laboratory guinea pig chow, the maize diet $(M)$ is composed of $100 \%$ maize, and the composition of two rehabilitation diets is detailed in Table 1 . In a first experiment (malnutrition study), 60 guinea pigs received either a balanced diet (control group, $n=30$ ) or a maize diet (malnourished group, $n=30$ ) for 7 , 12 , and $21 \mathrm{~d}(n=10$ per group). In a second experiment (nutritional rehabilitation study), 80 guinea pigs were divided into four dietary groups. A control group $(n=20)$ received the balanced diet for $21 \mathrm{~d}$. The remaining 60 guinea pigs were fed the maize diet for $12 \mathrm{~d}$ and then divided into three groups: in the first one, the animals were used immediately after the malnutrition period (malnourished group, $n=20$ ); in the second and third ones, the animals received a rehabilitation diet containing either soybean oil ( $S$ group, $n=20$ ) or palm oil ( $P$ group, $n=20$ ) during the next 9 d. Arrows indicate time of sacrifice. guinea pigs received either a standard laboratory guinea pig chow (well-nourished control group, $n=30$ ) or a polydeficient diet composed of maize only (malnourished group, $n=30$ ) for 7,12 , and $21 \mathrm{~d}$ ( $n=10$ per group).

A second experiment (nutritional rehabilitation study) was designed to test the effect of two different vegetable oils on specific intestinal measurements. Eighty guinea pigs were divided into four dietary groups. A control group $(n=20)$ received the balanced diet for $21 \mathrm{~d}$. The remaining 60 guinea pigs were fed the maize diet for $12 \mathrm{~d}$ and then divided into three groups: in the first one (malnourished group), the animals were used for experiments immediately after the 12-d malnutrition period $(n=20)$; in the second and third ones, during the next $9 \mathrm{~d}$, the animals received a rehabilitation diet containing either soybean oil $(n=20)$ or palm oil $(n=20)$. Then, the guinea pigs were anesthetized i.p. with $90 \mathrm{mg} / \mathrm{kg}$ sodium pentobarbital, after an overnight food deprivation, and killed. The small intestine was immediately collected for analysis.

The diet of the control group (laboratory guinea pig chow no. 106) was purchased from UAR (Villemoisson s/Orge, France). The deficient diet (100\% maize) and the two rehabilitation diets were purchased from INRA/APAE (Jouy en Josas, France). All diets were given ad libitum. Table 1 shows the composition of the control diet and the rehabilitation diets: they both contained $13 \% \mathrm{wt} / \mathrm{wt}$ lipids, in accordance with the recent recommendations on the dietary management of severe malnutrition (12). According to Cottrell (16), in soybean oil the main fatty acids were C18:2 (53.8\%), C18:1 (22\%), and C16:0 $(11.2 \%)$ and in palm oil they were C16:0 (43.8\%), C18:1 $(38.9 \%)$, and C18:2 (10.6\%). Red palm oil used was a gift from Palm Oil Research Institute of Malaysia.

Intestinal oxidative stress measurements. A part of the small intestine was flushed with saline to remove mucus and food

Table 1. Composition of rehabilitation diets*

\begin{tabular}{lc}
\hline \multicolumn{1}{c}{ Constituent } & $\begin{array}{c}\text { Amount } \\
(\mathrm{g} / 100 \mathrm{~g} \text { diet })\end{array}$ \\
\hline Casein & 14 \\
Sucrose & 18 \\
Starch & 37 \\
Cellulose & 10 \\
Soybean or palm oil & 13 \\
Mineral mixture $\dagger$ & 6.5 \\
Vitamin mixturet & 1 \\
L-Arginine & 0.25 \\
L-Methionine & 0.125 \\
L-Tryptophan & 0.125 \\
\hline
\end{tabular}

* Composition of the control commercial chow diet (g/100 g diet): proteins, 16; lipids, 3.5; carbohydrates, 50; cellulose, 13; moisture, 10.5; minerals, 6; vitamins, 1 (for mineral and vitamin mixture, see below).

$\dagger$ Mineral mixture (per kilogram diet): $\mathrm{CaHPO}_{4} \cdot 2 \mathrm{H}_{2} \mathrm{O}, 8.33 \mathrm{~g} ; \mathrm{CaCO}_{3}$, $14.56 \mathrm{~g} ; \mathrm{NaCl}, 2.81 \mathrm{~g} ; \mathrm{KCl}, 4.52 \mathrm{~g} ; \mathrm{CH}_{3} \mathrm{COOK}, 27.1 \mathrm{~g} ; \mathrm{FeSO}_{4} \cdot 7 \mathrm{H}_{2} \mathrm{O}, 0.4 \mathrm{~g}$; $\mathrm{MnSO}_{4} \cdot \mathrm{H}_{2} \mathrm{O}, 0.4 \mathrm{~g} ; \mathrm{MgSO}_{4} \cdot 7 \mathrm{H}_{2} \mathrm{O}, 1.5 \mathrm{~g} ; \mathrm{MgO}, 5 \mathrm{~g} ; \mathrm{CuSO}_{4} \cdot 5 \mathrm{H}_{2} \mathrm{O}, 0.04 \mathrm{~g}$; $\mathrm{NaF}, 0.04 \mathrm{~g}$; KI, $0.03 \mathrm{~g}$; $\left(\mathrm{NH}_{4}\right)_{6} \mathrm{Mo}_{7} \mathrm{O}_{24} \cdot 4 \mathrm{H}_{2} \mathrm{O}, 0.9 \mathrm{mg}$; $\mathrm{CoSO}_{4} \cdot 7 \mathrm{H}_{2} \mathrm{O}$, $0.03 \mathrm{~g} ; \mathrm{Na}_{2} \mathrm{SeO}_{3}, 0.9 \mathrm{mg} ; \mathrm{ZnSO}_{4} \cdot 7 \mathrm{H}_{2} \mathrm{O}, 0.2 \mathrm{~g}$.

\$ Vitamin mixture (per kilogram diet): retinyl acetate, 10,000 IU; cholecalciferol, 2,000 IU; DL- $\alpha$-tocopheryl acetate, $80 \mathrm{IU}$; menadione, $2 \mathrm{mg}$; thiamine $\mathrm{HCl}, 15 \mathrm{mg}$; riboflavin, $15 \mathrm{mg}$; nicotinic acid, $100 \mathrm{mg}$; calcium D-panthotenate, $30 \mathrm{mg}$; pyridoxine $\mathrm{HCl}, 10 \mathrm{mg}$; inositol, $1000 \mathrm{mg}$; D-biotin, $0.4 \mathrm{mg}$; folic acid, $6 \mathrm{mg}$; cyanocobalamin, $0.04 \mathrm{mg}$; ascorbic acid, $0.4 \mathrm{~g}$; paraaminobenzoic acid, $10 \mathrm{mg}$; choline $50 \% \mathrm{wt} / \mathrm{wt}, 2.75 \mathrm{~g}$; sucrose. 
residues, and slit open. The mucosa were scraped with the blunt edge of a glass slide, weighed, then washed three times by resuspending in a solution ( $\mathrm{pH}$ 7.4) of $10 \mathrm{mM}$ Tris- $\mathrm{HCl}, 150 \mathrm{mM}$ $\mathrm{KCl}$, and $1 \mathrm{mM}$ EDTA, and centrifuged for $5 \mathrm{~min}$ at $700 \times g$. The remaining pellet was homogenized in $3 \mathrm{vol}$ of the same buffer containing $0.25 \mathrm{mM}$ phenylmethylsulfonyl fluoride and frozen at $-80^{\circ} \mathrm{C}$ for later estimations. Protein content was determined according to Lowry et al. (17). Lipid peroxides (Tbars) were measured by a modification (18) of the method described by Ohkawa et al. (19). Tbars are a rough measure of malondialdehyde and similar byproducts of lipid peroxidation (20). The determination of carbonyl content in oxidatively modified proteins was assessed by the method of Levine et al. (21). Nonprotein sulfhydryl groups, mostly reduced glutathione, were determined by the method of Sedlak and Lindsay (22).

Intestinal electrical measurements in Ussing chambers. Another part of the small intestine was removed up to the cecum, starting $30 \mathrm{~cm}$ from the pylorus and, to remove the intestinal content, was carefully rinsed with cold Ringer's solution containing $(\mathrm{mM}): \mathrm{Na}^{+}, 140 ; \mathrm{K}^{+}, 5.2 ; \mathrm{Cl}^{-}, 120$; $\mathrm{HCO}_{3}{ }^{-}, 25 ; \mathrm{Ca}^{2+}, 1.2 ; \mathrm{HPO}_{4}{ }^{2-}, 2.4 ; \mathrm{H}_{2} \mathrm{PO}_{4}{ }^{-}, 0.4 ; \mathrm{Mg}^{2+}, 1.2$; and glutamine, $2 \mathrm{mM}$.

Jejunal segments from each animal were mounted in Ussing chambers as flat sheets with an exposed area of $0.5 \mathrm{~cm}^{2}$. They were bathed on both sides with $12 \mathrm{~mL}$ of Ringer's solution that was continuously warmed, circulated, oxygenated, and maintained at $\mathrm{pH} 7.4$ with $5 \% \mathrm{CO}_{2}$ in $95 \% \mathrm{O}_{2}$. The mucosal and serosal bathing solutions were connected via agar bridges to calomel electrodes for measurement of the transepithelial PD and to the $\mathrm{Ag}-\mathrm{AgCl}$ electrodes for applying the current. The tissue was kept under short-circuit conditions by an automatic clamping device (World Precision Instruments, Aston, U.K.) that canceled out the fluid resistance. The Isc was constantly recorded, and the tissue was pulsed at $0.5 \mathrm{mV}$ every $30 \mathrm{~s}$. Basal Isc was used as an index of total electrogenic ion movement. The deflection of Isc was used to calculate $G$ as an index of intestinal epithelial barrier integrity. Basal Isc, PD, and G were measured $30 \mathrm{~min}$ after tissue mounting.

Ki-67 antigen determination. The intestinal cell turnover was assessed by using the binding of Ki-67 antibody, which recognizes the cell cycle-dependent nuclear antigen Ki-67 in crypt cells (23-25). A part of the jejunum of each guinea pig (second experiment) was kept for the immunodetection of the cell cycle-dependent nuclear antigen Ki-67 in crypt cells. The tissues were fixed in Bouin's solution, embedded into paraffin blocks, and prepared in 5- $\mu \mathrm{m}$ sections. Antigen was unmasked, using $0.01 \mathrm{M}$ sodium citrate buffer $(\mathrm{pH}$ 6.0) boiling in a pressure cooker (26). The sections were then immunostained with the monoclonal mouse anti-human Ki-67 antibody, (clone MIB-1), which reacts with a nuclear nonhistone protein of 395 and $345 \mathrm{kD}$ present in all active phases of the cell cycle, i.e. $\mathrm{G}_{1}$, $\mathrm{S}, \mathrm{G}_{2}$, and $\mathrm{M}$ (mitosis), but is absent in $\mathrm{G}_{\mathrm{o}}(27,28)$. The antibody was revealed by incubation with biotinylated link antibody and peroxidase-labeled streptavidin.

For ease of counting we used an optical microscopic eyepiece graticule that divides the selected area in $500-\mu \mathrm{m}$ lengths. The number of labeled cells and crypts were respectively counted on this length. Twenty such measurements were performed per section. We defined the Ki-67 index as the ratio of the number of Ki-67-positive cells (i.e. brown-labeled cells) by the total number of crypts in the same given length of tissue.

Statistical analysis. Statistical means comparisons were made by ANOVA and by Duncan's multiple range test (29). Linear regression analysis was also used to determine the relationship between electrical measurement values and the duration of malnutrition (30). Results are means ( \pm SEM), with $n$ as the number of animals.

\section{RESULTS}

Nutritional data. In the first experiment (malnutrition study), two of 10 guinea pigs died in the group receiving the maize diet for $21 \mathrm{~d}$. The control guinea pigs gained weight regularly throughout the study. The malnourished guinea pigs showed a severe weight loss: their body weight decreased by $-26 \%$ and $-32 \%$ compared with control animals fed the balanced diet for the same period of time (after 12 and $21 \mathrm{~d}$, respectively; $p<0.001$ ). In the second experiment, two of 20 animals in the malnourished group, five of 20 in the soybean group, and two of 20 in the palm group died (statistically not significant). In the malnourished group after a period of weight loss caused by the $12 \mathrm{~d}$ of maize feeding $(-27 \%, p<0.001)$, a period of catch-up growth was observed with both rehabilitation diets. The $9 \mathrm{~d}$ of nutritional rehabilitation allowed only a partial recovery of weight compared with control animals. At the end of the study, the mean weight of rehabilitated guinea pigs was quite similar, but in the soybean group the mean weight was $83 \%(p<0.05)$ of the mean weight of control animals. In the palm group, the weight value reached $87 \%$, which is not statistically different from the value of the control group.

Intestinal oxidative stress. In both malnutrition (Table 2) and rehabilitation (Table 3) studies, the guinea pigs fed maize had higher levels of intestinal Tbars than control animals. In addition, mean Tbars levels increased progressively as malnutrition wors-

Table 2. Intestinal oxidative damage (first experiment)*

\begin{tabular}{cccc}
\hline $\begin{array}{c}\text { Duration of diet in d } \\
\text { (number of animals) }\end{array}$ & $\begin{array}{c}\text { Tbars } \\
\text { (pmol/mg protein) }\end{array}$ & $\begin{array}{c}\text { Prot-co } \\
\text { (nmol/mg protein) }\end{array}$ & $\begin{array}{c}\text { Non-protein SH } \\
(\mathrm{nmol} / \mathrm{mg} \text { protein) }\end{array}$ \\
\hline $0(30)$ & $109 \pm 14$ & $3.80 \pm 0.36$ & $15.9 \pm 0.67$ \\
$7(10)$ & $132 \pm 25$ & $4.45 \pm 0.57$ & $15.6 \pm 0.43$ \\
$12(10)$ & $136 \pm 38$ & $2.89 \pm 0.35$ & $17.6 \pm 0.95$ \\
$21(8)$ & $158 \pm 19$ & $3.11 \pm 0.46$ & $17.2 \pm 0.79$ \\
\hline
\end{tabular}

* Oxidative stress markers in small intestinal mucosa of guinea pigs fed a maize diet for 7, 12, or $21 \mathrm{~d}$. Results are expressed as the mean \pm SEM. Means are not significantly different $(p>0.05)$, but see "Results" for statistical analysis of Tbars content.

Abbreviations: Prot-co, protein carbonyls; SH, sulfhydryls. 
Table 3. Intestinal oxidative damage (second experiment)*

\begin{tabular}{lccc}
\hline \multicolumn{1}{c}{$\begin{array}{c}\text { Diet } \\
\text { (number of animals) }\end{array}$} & $\begin{array}{c}\text { Tbars } \\
(\mathrm{nmol} / \mathrm{mg} \text { protein })\end{array}$ & $\begin{array}{c}\text { Prot-co } \\
\text { (nmol/mg protein) }\end{array}$ & $\begin{array}{c}\text { Non-protein SH } \\
(\mathrm{nmol} / \mathrm{mg} \text { protein) }\end{array}$ \\
\hline Control (20) & $96.3 \pm 9.1$ & $3.36 \pm 0.42$ & $14.8 \pm 1.0$ \\
Maize (18) & $143 \pm 24$ & $3.66 \pm 0.33$ & $16.1 \pm 0.7$ \\
Maize followed by soybean (15) & $138 \pm 22$ & $4.03 \pm 0.57$ & $16.7 \pm 0.8$ \\
Maize followed by palm (18) & $106 \pm 19$ & $4.67 \pm 0.50$ & $16.0 \pm 0.7$ \\
\hline
\end{tabular}

* Oxidative stress markers in small intestinal mucosa of guinea pigs fed a maize diet for $12 \mathrm{~d}$ and then a rehabilitation diet containing palm or soybean oil for $9 \mathrm{~d}$. Results are expressed as the mean \pm SEM. The malnourished group is composed of guinea pigs fed a polydeficient maize diet for $12 \mathrm{~d}$. The soybean and palm groups are composed of guinea pigs fed a polydeficient maize diet for $12 \mathrm{~d}$ and then a rehabilitation diet for $9 \mathrm{~d}$ containing palm or soybean oil, respectively. Means are not significantly different $(p>0.05)$, but see "Results" for statistical analysis of Tbars content.

Abbreviations as in Table 2.

ened (Table 2). However, when ANOVA tests were performed separately for each study, there was no statistically significant difference among groups, probably owing to the high intragroup variability of values. To gain statistical power, we performed another statistical analysis taking into account the results from both studies. In this case, Tbars levels were actually significantly increased, on average $+40 \%(p<0.05)$ in malnourished animals fed the maize diet for $12 \mathrm{~d}$ compared with all control animals that constitute a statistically homogeneous group $\left(F_{3,46}=0.435 ; p>\right.$ $0.05): 146 \pm 21(n=28)$ versus $104 \pm 7(n=50) \mathrm{pmol} / \mathrm{mg}$ protein. Interestingly, after nutritional rehabilitation with the soybean oil diet, Tbars remained elevated $(+43 \%)$, whereas they decreased with the palm oil diet $(+10 \%)$ to reach control levels (Table 3). In contrast, protein carbonyls and nonprotein sulfhydryl levels were not altered by malnutrition (Table 2) or nutritional rehabilitation (Table 3).

Intestinal function. Basal jejunal electrical variables are reported in Table 4 for the malnutrition study. Both Isc and PD increased significantly after $21 \mathrm{~d}$ of malnutrition compared with control animals $(+54 \%$ and $+65 \%$, respectively; $p<$ $0.001)$. In addition, the percentage of variation of both Isc and PD in malnourished versus control animals was significantly and positively associated with the duration of malnutrition. Linear regression analysis gave $r^{2}$ determination coefficients equal to 0.346 and 0.459 for the relationship between the duration of malnutrition (in days) and the percentage Isc and PD variations, respectively $(p<0.001)$. As shown in Table 5 , nutritional rehabilitation with either soybean or palm diets allowed a return of both Isc and PD to values not significantly different from control values. Transepithelial $\mathrm{G}$ was not altered in any experimental condition (Tables 4 and 5).

Ki-67 index. In the second experiment, the means for the Ki-67 index values in the control $(1.03 \pm 0.15, n=20)$, malnourished $(1.29 \pm 0.17, n=18)$, and palm oil rehabilitated $(1.16 \pm 0.11, n$ $=18$ ) animals were not different. In the rehabilitated animals fed soybean oil, the Ki-67 index was lower $(0.41 \pm 0.06, n=15 ; p$ $<0.01)$ compared with the Ki-67 index from the guinea pigs fed palm oil. The immunohistochemical stainings (brown-labeled cells) of the jejunum from soybean and palm oil rehabilitated guinea pigs are shown in Figure 2.

\section{DISCUSSION}

These results confirm that experimental malnutrition induces oxidative damage (31) and stimulates electrogenic ion movement (11) in the small intestine. They show that palm oil is at least as effective as soybean oil in promoting weight gain; they also suggest a better effect of palm oil on Tbars levels and intestinal function repair during nutritional rehabilitation. In addition, they suggest that soybean oil may reduce intestinal cell turnover compared with palm oil. Taken together, these data suggest that the composition of vegetable oil in the diet may alter intestinal function and cell cycle by a mechanism that includes an effect on oxidative stress.

The present model of experimental malnutrition was based on the observation that the low dietary quality of the cereal-based diets currently used as weaning diets in poor areas of the world may explain the high prevalence of child malnutrition in those areas (32). Malnutrition cannot be considered solely a deficiency in proteins and in energy (1). In the present study, malnutrition in guinea pigs was induced by maize feeding $(100 \%)$ for $7-21 \mathrm{~d}$. As expected, the maize diet induced weight loss and increased intestinal oxidative stress as well as compromising intestinal function. Golden and Ramdath (8) hypothesized that cell damage from free radicals leads to edema, fatty infiltration of the liver, and skin lesions in children with kwashiorkor. This theory, however, has not been firmly established or subjected to the test of animal experiments (33). Although the gastrointestinal tract has a particularly enhanced capacity to provide protection against lipid peroxidation (34), our data suggested that the Tbars level increased during the time course of malnutrition. The present results are therefore consistent with an oxidative stress on the intestine in experimental malnutrition.

Malnutrition was also associated with intestinal dysfunction. Basal Isc was increased in malnourished guinea pigs, and this rise was significantly correlated with the duration of malnutrition. This suggests that electrolyte active transporters are activated by malnutrition. In fact, previous studies in malnourished rats suggest that such a rise in basal Isc reflects an activation of the intestinal secretion of chloride and water (35), which is consistent with the high prevalence of diarrhea observed in

Table 4. Epithelial integrity (first experiment)*

\begin{tabular}{cccc}
\hline $\begin{array}{c}\text { Duration of diet in } \mathrm{d} \\
\text { (number of animals) }\end{array}$ & $\begin{array}{c}\mathrm{Isc} \\
\left(\mu \mathrm{A} / \mathrm{cm}^{2}\right)\end{array}$ & $\begin{array}{c}\mathrm{G} \\
\left(\mathrm{mS} / \mathrm{cm}^{2}\right)\end{array}$ \\
\hline $0(30)$ & $21.3 \pm 0.8$ & $-2.14 \pm 0.09$ & $20.7 \pm 0.6$ \\
$7(10)$ & $22.4 \pm 1.2$ & $-2.35 \pm 0.14$ & $21.1 \pm 1.0$ \\
$12(10)$ & $26.0 \pm 2.1$ & $-2.57 \pm 0.21$ & $18.9 \pm 1.8$ \\
$21(8)$ & $32.8 \pm 1.7 \dagger$ & $-3.53 \pm 0.21 \dagger$ & $19.9 \pm 1.4$ \\
\hline
\end{tabular}

* Basal electrical measurements in isolated jejunal mucosa of guinea pigs fed a maize diet for 7, 12, or $21 \mathrm{~d}$. Results are expressed as the mean \pm SEM. $\dagger p<0.001$, significantly different from the control group. 
Table 5. Epithelial integrity and cell multiplication (second experiment)*

\begin{tabular}{lcccc}
\hline \multicolumn{1}{c}{ Diet (number of animals) } & $\begin{array}{c}\text { Isc } \\
\left(\mu \mathrm{A} / \mathrm{cm}^{2}\right)\end{array}$ & $\begin{array}{c}\text { PD } \\
(\mathrm{mV})\end{array}$ & $\begin{array}{c}\mathrm{G} \\
\left(\mathrm{mS} / \mathrm{cm}^{2}\right)\end{array}$ & $\begin{array}{c}\mathrm{Ki}-67 \mathrm{index} \\
(\mathrm{labeled} \mathrm{cells/crypt})\end{array}$ \\
\hline Control (20) & $19.5 \pm 0.7$ & $-2.12 \pm 0.13$ & $18.2 \pm 0.7$ & $1.03 \pm 0.15$ \\
Maize (18) & $24.7 \pm 1.1 \dagger$ & $-2.54 \pm 0.12 \dagger$ & $20.0 \pm 1.0$ & $1.29 \pm 0.16$ \\
Maize followed by soybean (15) & $21.1 \pm 0.7$ & $-2.18 \pm 0.06$ & $18.7 \pm 0.5$ & $0.41 \pm 0.05+$ \\
Maize followed by palm (18) & $17.2 \pm 1.2$ & $-1.98 \pm 0.11$ & $19.1 \pm 0.9$ & $1.16 \pm 0.11$ \\
\hline
\end{tabular}

* Basal electrical measurements and $\mathrm{Ki}-67$ index in isolated jejunal mucosa of guinea pigs fed a maize diet for $12 \mathrm{~d}$ and then a rehabilitation diet containing palm or soybean oil for $9 \mathrm{~d}$. Results are expressed as the mean \pm SEM. The malnourished group is composed of guinea pigs fed a maize diet for $12 \mathrm{~d}$.

$\dagger p<0.05, \ddagger p<0.01$ significantly different from the control group.
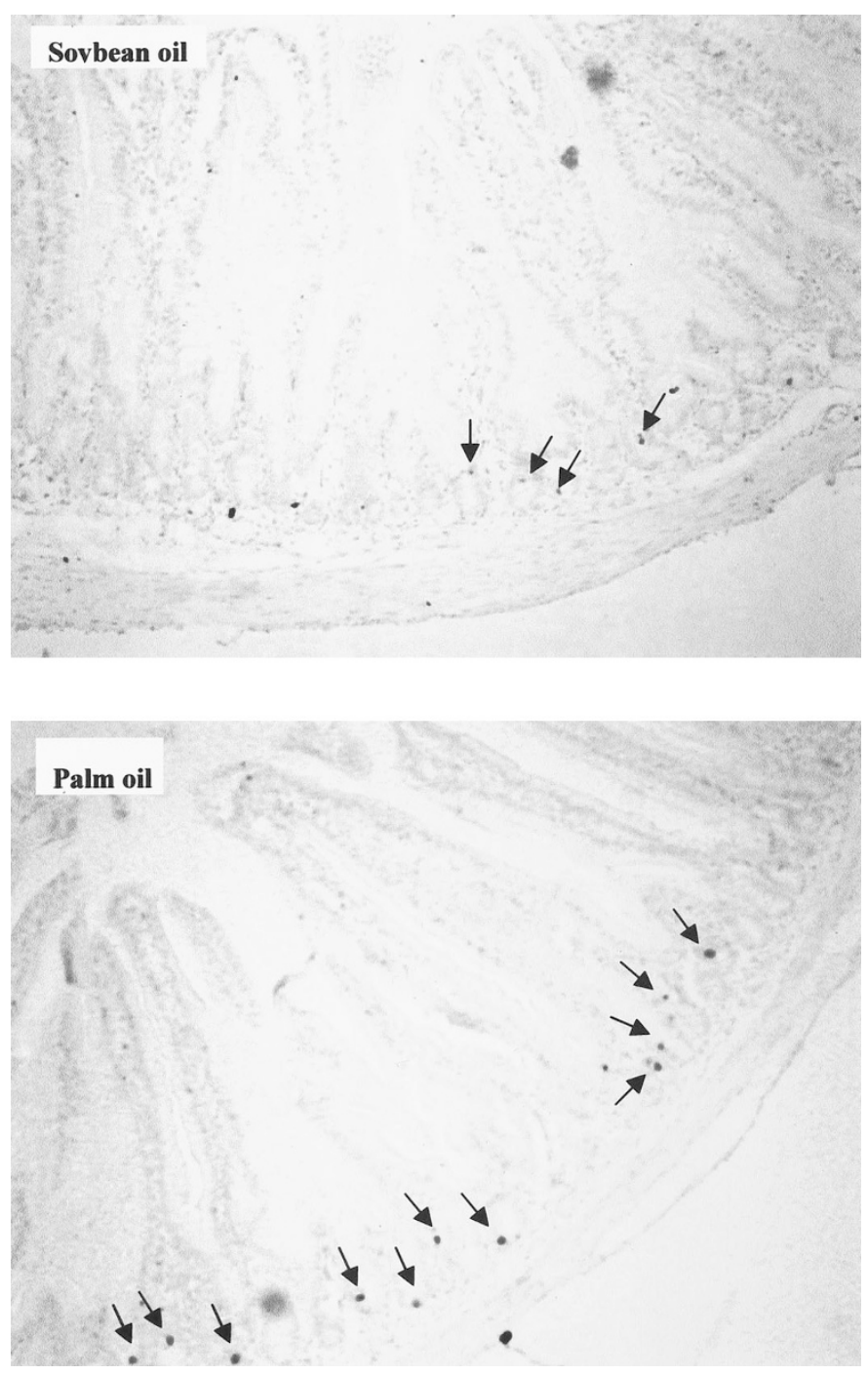

Figure 2. Immunohistochemical staining of paraffin-embedded sections with $\mathrm{Ki}-67$ of guinea pig jejunum from soybean oil-replenished ( $S$ group) and palm oil-replenished ( $P$ group). Arrows indicate brown cells exhibiting a positive staining. An obviously greater number of cells are present in the mucosa of guinea pigs from the $\mathrm{P}$ group compared with the $\mathrm{S}$ group. Ki-67 is a cell cycle-dependent antigen, and its presence reflects intestinal cell turnover.

malnourished children (36). In this study, we did not observe an alteration of transepithelial $\mathrm{G}$, an index of the functional integrity of the intestinal barrier. This is different from previous studies in which we found an increase in G, both in rats (11) and in guinea pigs (37) fed a low protein diet. Also, in guinea pigs malnourished with a diet composed of $96 \%$ maize and $4 \%$ milk proteins for $4 \mathrm{wk}$, we previously found an increase in the ionic $\mathrm{G}$ but not in basal Isc or PD (15). Therefore, these findings about the impact of experimental malnutrition on intestinal function cannot be attributed to species differences or experimental models of malnutrition. Alternatively, they could be related to the duration and severity of malnutrition. Notably, in maize-fed guinea pigs, after $3 \mathrm{wk}$ of polydeficient malnutrition (present study), the mortality reached $20 \%$, whereas it reached $55 \%$ after $4 \mathrm{wk}(15)$. We speculate that the increase in ionic $\mathrm{G}$ previously observed in animals surviving from $4 \mathrm{wk}$ of malnutrition may be the last event in the process of intestinal epithelium alteration induced by malnutrition.

It is well documented that children with severe malnutrition have a low intestinal cell renewal (36). We thus studied the Ki-67 index, which is usually interpreted as an index of cell turnover $(24,38,39)$, but in the present study, in the malnourished animals the Ki-67 index was not reduced; in fact we observed a $21 \%$ increase, compared with control values. The present results may thus be differently interpreted: the higher Ki-67 index could be related to a longer cell cycle time induced by malnutrition, as reported in experimental malnutrition of suckling rats (40). Alternatively, reactive oxygen species are known to modulate cell cycle. Hydrogen peroxide has been reported to stimulate the activity of the mitogen-activated protein kinases, extracellular signal-regulated kinases, and c-Jun amino-terminal kinase and the expression of the proto-oncogenes $c$-fos and $c$-jun (41). In this context, the interpretation of an increased Ki-67 index would be a longer cell cycle because of malnutrition or an increase in cell turnover as a consequence of the oxidative stress associated with malnutrition.

After the malnutrition period, whatever the source of dietary fat, a rapid recovery in weight gain was observed during rehabilitation, but a complete catch-up growth was not obtained. The final weight of guinea pigs was higher when the nutritional rehabilitation was conducted with palm oil than with soybean oil. Although this difference was not significant, it could possibly reflect a better net protein utilization, as previously shown in growing rats (42).

In agreement with our hypothesis, Tbars concentration was not altered after soybean oil feeding, but decreased after palm oil. In fact, we found that the level of lipid peroxides in malnourished guinea pigs treated with palm oil were similar to those in wellnourished control animals. This may be explained by the fact that palm oil is very rich in tocopherols and tocotrienols and has a low content of polyunsaturated fatty acids compared with soybean oil. Moreover, the high oleic acid content of palm oil may reinforce the antioxidant capacity of the diet, because the major factor responsible for the inhibition of lipid peroxidation in the gastro- 
intestinal mucosal membranes was isolated and chemically characterized as oleic acid (43). This nonesterified fatty acid probably forms complexes with iron, making it unavailable for induction of peroxidation (44).

Changing the quantity and the quality of dietary lipid is known to modify the fatty acid composition of the intestinal epithelium (45). In keeping with lipid membrane composition playing an important role in ion transport (46), our data indicate that $9 \mathrm{~d}$ of feeding diets containing $13 \% \mathrm{wt} / \mathrm{wt}$ soybean or palm oil was sufficient to normalize the altered intestinal electrolyte transport. Likewise, diets low in polyunsaturated fatty acids have been previously shown to be associated with a decrease in basal intestinal Isc (47).

Finally, the Ki-67 index was very different in palm and soybean oil-treated malnourished animals. These results are in keeping with the described effect of fatty acids on cell cycle (48-50). Whatever the molecular mechanism involved in the interaction among dietary lipids, malnutrition, and oxidative stress, the present results clearly indicate a difference in the intestinal cell turnover according to the nature of the dietary lipids.

In conclusion, this study indicates that polydeficient malnutrition is associated in the guinea pig with growth impairment and concomitant signs of free radical damage and altered electrolyte transport and cell turnover at the intestinal level. It also suggests that the degree of saturation of fatty acids present in the diet has an effect on these intestinal measurements. Thus, the present results point to the importance of taking into account the nature of the dietary lipids for further research in the treatment of childhood malnutrition.

\section{REFERENCES}

1. Golden MHN 1995 Severe malnutrition. In: Weatherall DJ, Ledingham JGG, Warell DA (eds) The Oxford Textbook of Medicine. University Press, pp 1278-1296

2. Mathias PM 1983 Vitamin E status of children recovering from severe malnutrition. Proc Nutr Soc 41:143A

3. Smith FR, Goodman DS, Zaklama MS, Gabr MK, el Maraghy S, Patwardhan VN 1973 Serum vitamin A, retinol-binding protein, and prealbumin concentrations in protein-calorie malnutrition. I. A functional defect in hepatic retinol release. Am J Clin Nutr 26:973-981

4. Becker K, Botticher D, Leichsenring M 1994 Antioxidant vitamins in malnourished Nigerian children. Int J Vitam Nutr Res 64:306-310

5. Jackson AA 1986 Blood glutathione in severe malnutrition in childhood. Trans R Soc Trop Med Hyg 80:911-913

6. Becker K, Leichsenring M, Gana L, Bremer HJ, Schirmer RH 1995 Glutathione and association antioxidant systems in protein energy malnutrition: results of a study in Nigeria. Free Radic Biol Med 18:257-263

7. Ogasawara T, Ohnhaus EE, Hoensch HP 1989 Glutathione and its related enzymes in the small intestinal mucosa of rats: effects of starvation and diet. Res Exp Med (Berl) 189:195-204

8. Golden MHN, Ramdath D 1987 Free radicals in the pathogenesis of kwashiorkor. Proc Nutr Soc 46:53-68

9. Dempster WS, Sive AA, Rosseau S, Malan H, Heese HV 1995 Misplaced iron in kwashiorkor. Eur J Clin Nutr 49:208-210

10. Sive AA, Dempster WS, Malan H, Rosseau S, Heese HD 1997 Plasma free iron: a possible cause of oedema in kwashiorkor. Arch Dis Child 76:54-56

11. Darmon N, Pelissier MA, Heyman M, Albrecht R, Desjeux JF 1993 Oxidative stress may contribute to the intestinal dysfunction of weanling rats fed a low protein diet. J Nutr 123:1068-1075

12. World Health Organization 1999 Management of Severe Malnutrition: A Manual for Physicians and Other Health Workers. World Health Organization, pp 1-60

13. Scrimshaw NS 2000 Nutritional potential of red palm oil for combating vitamin A deficiency. Food Nutr Bull 21:195-211

14. Wills ED 1985 The role of dietary components in oxidative stress in tissues. In: Sies H (ed) Oxidative Stress. Academic Press, London, pp 197-218

15. Darmon N, Abdoul E, Roucayrol AM, Blaton MA, Briend A, Desjeux JF, Heyman M 1998 Sensitization to cow's milk proteins during refeeding of guinea pigs recovering from polydeficient malnutrition. Pediatr Res 44:931-938

16. Cottrell R 1991 Introduction: nutritional aspects of palm oil. Am J Clin Nutr 53:989S-1009S

17. Lowry OH, Rosebrough NJ, Farr AL, Randall RJ 1951 Protein measurement with the Folin phenol reagent. J Biol Chem 193:265-275
18. Albrecht R, Pelissier MA, Atteba S, Smaili M 1992 Dietary restriction decreases thiobarbituric acid-reactive substances generation in the small intestine and in the liver of young rats. Toxicol Lett 63:91-96

19. Ohkawa H, Ohishi N, Yagi K 1979 Assay for lipid peroxides in animal tissues by thiobarbituric acid reaction. Anal Biochem 95:351-358

20. Janero DR 1990 Malondialdehyde and thiobarbituric acid-reactivity as diagnostic indices of lipid peroxidation and peroxidative tissue injury. Free Radic Biol Med 9:515-540

21. Levine RL, Garland D, Oliver CN, Amici A, Climent I, Lenz AG, Ahn BW, Shaltiel S, Stadtman ER 1990 Determination of carbonyl content in oxidatively modified proteins. Methods Enzymol 186:464-478

22. Sedlak J, Lindsay RH 1968 Estimation of total, protein-bond, and, nonprotein sulfhydryl groups in tissue with Ellman's reagent. Anal Biochem 25:192-205

23. Okudela K, Ito T, Mitsui H, Hayashi H, Udaka N, Kanisawa M, Kitamura H 1999 The role of p53 in bleomycin-induced DNA damage in the lung: a comparative study with the small intestine. Am J Pathol 155:1341-1351

24. Shmakov AN, Morey AL, Ferguson DJ, Fleming KA, O’Brien JA, Savidge TC 1995 Conventional patterns of human intestinal proliferation in a severe-combined immunodeficient xenograft model. Differentiation 59:321-330

25. Lee CS 1996 Differences in cell proliferation and prognostic significance of proliferating cell nuclear antigen and Ki-67 antigen immunoreactivity in in situ and invasive carcinomas of the extrahepatic biliary tract. Cancer 78:1881-1887

26. Cattoretti G, Becker MH, Key G, Duchrow M, Schluter C, Galle J, Gerdes J 1992 Monoclonal antibodies against recombinant parts of the Ki-67 antigen (MIB 1 and MIB 3) detect proliferating cells in microwave-processed formalin-fixed paraffin sections. J Pathol 168:357-363

27. Gerdes J, Becker MH, Key G, Cattoretti G 1992 Immunohistological detection of tumour growth fraction (Ki-67 antigen) in formalin-fixed and routinely processed tissues. [letter] J Pathol 168:85-86

28. Key G, Petersen JL, Becker MH, Duchrow M, Schluter C, Askaa J, Gerdes J 1993 New antiserum against Ki-67 antigen suitable for double immunostaining of paraffin wax sections. J Clin Pathol 46:1080-1084

29. Duncan DB 1955 Multiple range and multiple $F$ tests. Biometrics 11:1-6

30. Lellouch J, Lazar P 1974 Régression linéaire. In: Flammarion (ed) Méthodes Statistiques en Expérimentation Biologique. Médecine Sciences, Paris, pp 154-164

31. Pelissier MA, Darmon N, Desjeux JF, Albrecht R 1993 Effects of protein deficiency on lipid peroxidation in the small intestine and liver of rats. Food Chem Toxicol 31:59-62

32. Brown KH 1991 The importance of dietary quality versus quantity for weanlings in less developed countries: a framework of discussion. Food Nutr Bull 13:86-92

33. Albrecht R, Pelissier MA 1995 About the oxidative stress status in children with kwashiorkor. Food Chem Toxicol 33:1081-1083

34. Diplock AT, Balasubramanian KA, Manohar M, Mathan VI 1988 Purification and chemical characterization of the inhibitor of lipid peroxidation from intestinal mucosa. Biochim Biophys Acta 962:42-50

35. Young A, Levin RJ 1990 Diarrhoea of famine and malnutrition: investigations using a rat model. 1. Jejunal hypersecretion induced by starvation. Gut 31:43-53

36. Brunser O, Araya M, Espinoza J 1990 Gastrointestinal changes in the malnourished child. In: Suskind RM, Lewinter-Suskind L (eds) The Malnourished Child. Raven Press, New York, pp 261-276

37. Darmon N, Heyman M, Candalh C, Blaton MA, Desjeux JF 1996 Anaphylactic intestinal response to milk proteins during malnutrition in guinea pigs. Am J Physiol 270:G442-G448

38. Mills SJ, Shepherd NA, Hall PA, Hastings A, Mathers JC, Gunn A 1995 Proliferative compartment deregulation in the non-neoplastic colonic epithelium of familial adenomatous polyposis. Gut 36:391-394

39. Berenzi A, Benetti A, Bertalot G, Rodolfi A, Portolani N, Giulini SM, Pulcini G, Vinco A, Tiberio G 1992 Ki67 immunohistochemical evaluation in colorectal cancer and normal colonic mucosa: possible clinical applications. Pathologica 84:155-163

40. Gomez JL, Campos C, Rangel P, Ortiz R 1996 Cell cycle phase duration in bone marrow cells from malnourished rats during suckling. Mutat Res 352:57-60

41. Tournier C, Thomas G, Pierre J, Jacquemin C, Pierre M, Saunier B 1997 Mediation by arachidonic acid metabolites of the $\mathrm{H}_{2} \mathrm{O}_{2}$-induced stimulation of mitogenactivated protein kinases (extracellular-signal-regulated kinase and c-Jun $\mathrm{NH}_{2}$ terminal kinase). Eur J Biochem 244:587-595

42. Henry CJ, Ghusain-Choueiri A, Gurr MI 1999 Influence of palm olein on protein utilisation in the growing rat. Int J Food Sci Nutr 50:85-94

43. Balasubramanian KA, Nalini S, Manohar M 1992 Nonesterified fatty acids and lipid peroxidation. Mol Cell Biochem 111:131-135

44. Nalini S, Balasubramanian KA 1991 Effect of exposure of various oxidants on rat liver and intestinal microsomes: a comparative study. Chem Biol Interactions 80:135-144

45. Lindley KJ, Muller DP, Milla PJ 1995 Effects of dietary polyunsaturated fatty acids on small intestinal secretory and absorptive function: studies in rat jejunum in vitro. Clin Sci 88:219-224

46. Dodge JA 1994 Dietary fats and gastrointestinal function. Eur J Clin Nutr 48:S8-S16

47. Cartwright-Shamoon JM, Dodge JA, McMaster C 1995 A complex biochemical modulation of intestinal ion transport in rats fed on high-fat diets. J Pediatr Gastroenterol Nutr 20:36-43

48. Diggle CP, Pitt E, Roberts P, Trejdosiewicz LK, Southgate J 2000 N;-3 and n;-6 polyunsaturated fatty acids induce cytostasis in human urothelial cells independent of p53 gene function. J Lipid Res 41:1509-1515

49. Davidson LA, Brown RE, Chang WC, Morris JS, Wang N, Carroll RJ, Turner ND, Lupton JR, Chapkin RS 2000 Morphodensitometric analysis of protein kinase C beta(II) expression in rat colon: modulation by diet and relation to in situ cell proliferation and apoptosis. Carcinogenesis 21:1513-1519

50. Izushina Y, Sagisaka M, Sakaib H, Abeb M, Sakaguchi K 2000 Mode analysis of binding of fatty acids to mammalian DNA polymerases. Biochim Biophys Acta 1486:211-218 